\title{
KESALAHAN SINTAKSIS PADA SKRIPSI MAHASISWA S1 \\ UIN SUNAN KALIJAGA YOGYAKARTA
}

\author{
M Ilzam Kamaludin
}

UIN Sunan Kalijaga Yogyakarta

Email: ilzam_79@yahoo.co.id

$$
\begin{aligned}
& \text { التجريل } \\
& \text { "هذه الكتابة تكشف عن أخطاء الطلاب في كتابات البحث من ناحية تراكيب اللغة العببية للطلاب في قسم اللغة } \\
& \text { العربية بكلية التربية وقسم اللغة العربية وأدبما بكلية الأدب وعلم الثقافة جامعة سونان كليجاكا يوكياكرتا، والتراكيب } \\
& \text { المقصودة هي المركبات وتنقسم إلى التركيب الإسنادي والتركيب الإضافي والتركيب البياني والتركيب العطفي والتركيب } \\
& \text { المزجي والتركيب العلدي. وهنه الكتابة باستخدام البحث الكيفي، والمنهج الني استخدمه الكاتب هو المنهج } \\
& \text { التحليلي عن الأخطاء اللغوية. ؤاما العينة فهي سبعة البحوث بين الطلاب بكلية التربية للغة العربية وقسم اللغة } \\
& \text { العربية وأدجا. بعد أن حلل الكاتب عن كتابات البحث، نال الكاتب الأخطاء الكثيرة، أنها تتضمن من الجملة }
\end{aligned}
$$

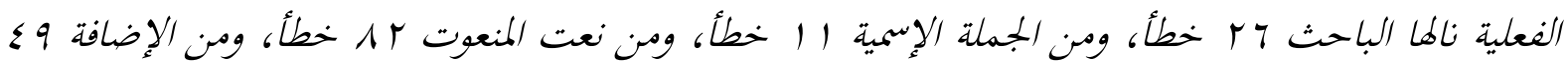

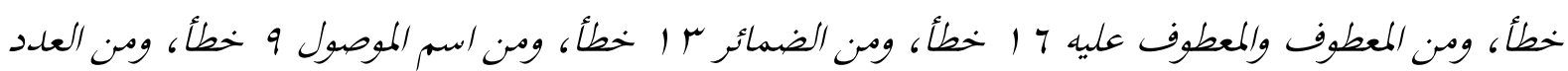

$$
\begin{aligned}
& \text { والمعدود خطأ واحد فحسب، وأما تلك الأخطاء المجموعة فهي V. . خ خطأ. " } \\
& \text { مفتاح الكلمات: تحليل الأخطاء اللغوية، مهارة الكتابة، المركبات النحوية }
\end{aligned}
$$

\section{PENDAHULUAN}

Bahasa Arab merupakan suatu ilmu yang diarahkan untuk mendorong, membimbing, mengembangkan, dan menumbuhkan sikap positif terhadap bahasa arab tersebut, baik represif maupun produktif. Bahasa Arab juga merupakan salah satu mata pelajaran yang menempati posisi yang penting dalam dunia pendidikan di Indonesia.

Di dalam bahasa Arab terdapat 4 keterampilan dasar, yaitu: keterampilan menyimak (al-istimā'), berbicara (al-kalām), membaca (al-qirā'ah), dan menulis (al-kitābah). Salah satu aspek dari keterampilan berbahasa, menulis merupakan kegiatan yang kompleks, Kompleksitas menulis terletak pada tuntutan kemampuan penulis untuk menata dan mengorganisasikan ide 


\section{Ilzam Kamaludin}

secara sistematis dan logis, serta menyajikannya dalam ragam bahasa tulis sesuai kaidah penulisan. $^{1}$

Menurut Rusyana (1998) menulis merupakan kemampuan menggunakan pola-pola bahasa secara tertulis untuk mengungkapkan suatu gagasan atau pesan, sedangkan Tarigan (1989) mendefinisikan menulis sebagai proses menggambarkan suatu bahasa sehingga pesan yang disampaikan penulis dapat dipahami pembaca. Kedua pendapat tersebut sama-sama mengacu kepada menulis sebagai proses melambangkan bunyi-bunyi ujaran berdasarkan aturan-aturan tertentu. $^{2}$

Salah satu bagian dari keterampilan menulis adalah mengarang. Mengarang dalam bahasa Arab disebut dengan (al-insy $\bar{a}^{\prime}$ ) yaitu secara etimologis berarti menyusun, menghimpun, membangun, mendirikan, dan mengarang. ${ }^{3}$ kemudian secara istilah berarti kegiatan menyusun kata-kata dalam kalimat secara benar dan sesuai dengan kaidah tata bahasa. Penulis menghubung-hubungkan kalimat-kalimat tersebut hingga terbentuk suatu tulisan yang berkesinambungan yang dapat mengkomunikasikan pikiran dan ide penulis tentang suatu topik tertentu. Untuk memperoleh keterampilan menulis, khususnya menulis karya ilmiah, diperlukan suatu proses yang berupa pembelajaran dan pelatihan menulis. Keduanya merupakan dua kegiatan yang berkesinambungan, terfokus pada aktifitas siswa atau mahasiswa untuk mendapatkan suatu keterampilan tertentu, yang dalam hal ini adalah keterampilan menulis. ${ }^{4}$

Dengan demikian mahārah al-kitābah (keterampilan menulis) adalah kemampuan seseorang dalam mengolah lambang-lambang grafis menjadi kata-kata, lalu kata-kata menjadi kalimat yang efektif yang sesuai dengan kaidah bahasa yang berlaku, guna menyampaikan dan menginformasikan ide, buah pikiran, pendapat, pengalaman, sikap, dan perasaan kepada orang lain. $^{5}$

Bahasa Arab sebagai bahasa Asing bagi bahasa Indonesia, dipandang memiliki kedudukan yang penting di tengah masyarakat karena bahasa Arab adalah juga dipandang

\footnotetext{
${ }^{1}$ Syamsi Setiadi, "Peningkatan Keterampilan Kitabah Arabiyah Mahasiswa Melalui Metode Tutor Sebaya", jurnal al-bayān (No. 1 tahun 2017), hlm. 31

2 Abd. Wahab Rosyidi dan Mamlu'atul Ni'mah, Memahami Konsep Dasar, hlm. 97.

${ }^{3}$ Moh Mansyur Kustiwan, دليل الكاتب والمرتجم, (Jakarta: Moyo Segoro Agung, 2002), hlm. 1.

${ }^{4}$ Pangesti Wiedarti, Menuju Budaya Menulis Suatu Bunga Rampai, (Yogyakarta: Tiara Wacana, 2005), hlm.1.

${ }^{5}$ Aziz Fachrurrozi dan Erta Mahyuddin, Teknik Pembelajaran Bahasa Arab, (Bandung: Pustaka Cendekia Utama, 2011), hlm. 144.
} 
sebagai bahasa agama Islam. Bahasa Arab memiliki karakteristik yang sangat berbeda dari bahasa Indonesia pada aspek morfologis, sintaksis dan semantis. Hal inilah yang menjadikan bahasa Arab tidak mudah untuk dikuasai oleh para pelajar. Karakteristik bahasa Arab (dalam menulis berbahasa Arab) ini harus dikuasai dengan baik oleh mahasiswa jurusan Pendidikan Bahasa Arab (PBA) di Fakultas Ilmu Tarbiyah dan Keguruan (FITK) karena mereka berorientasi menjadi calon guru bahasa Arab pada generasi yang akan datang, dan tidak kalah penting juga bahwa menulis berbahasa Arab juga harus dikuasai oleh mahasiswa Bahasa dan Sastra Arab (BSA) di Fakultas Ilmu Adab dan Budaya (FADIB) UIN Sunan Kalijaga Yogyakarta, karena mereka juga mempunyai orientasi penting dalam bidang bahasa Arab seperti penerjemah, penulis dan lain-lain.

Dengan demikian, dalam menulis bahasa Arab mahasiswa menghadapi dua kendala yaitu mengemukakan ide tertulis secara sistematis dan menyusun rangkaian kalimat bahasa Arab. ${ }^{6}$

Setelah penulis melakukan observasi terhadap penulisan skripsi mahasiswa jurusan Pendidikan Bahasa Arab di FITK dan Bahasa dan Sastra Arab di FADIB UIN Sunan Kalijaga Yogyakarta, yang mana sistematika penulisan skripsi pada jurusan PBA menggunakan dua bahasa pilihan, yaitu bahasa Indonesia atau bahasa Arab, tetapi untuk jurusan BSA mewajibkan mahasiswanya menulis skripsi dengan menggunakan bahasa Arab saja. Dari hasil observasi, terdapat beberapa masalah dalam penulisannya, diantaranya adalah kesalahan dalam aspek sintaksis penulisan seperti kalimat القائدة الإملاء dan واجهت الباحث, dari kedua susunan tersebut terdapat kesalahan, yang pertama واجهت الباحث yang mempunyai arti "peneliti menghadapi” yang benar adalah واجه الباحث karena susunan tersebut tidak sesuai dengan ḍamir yang digunakan dalam membuat jumlah fi'liyyah, bahwasanya ḍamir yang digunakan penulis adalah ḍamir muannats sedangkan subjek ( $\left.f \bar{a}^{\prime} i l\right)$ dari kalimat tersebut berupa mudzakkar, dan قائدة القائدة الإملاء yang artinya "kaidah/teori imlä," benar adalah الإملاء karena susunan kalimat tersebut termasuk iḍfah bukan na'at man'üt karena kata

${ }^{6}$ Syamsi Setiadi, "Peningkatan Keterampilan Kitabah Arabiyah Mahasiswa Melalui Metode Tutor Sebaya", jurnal al-bayān (No. 1 tahun 2017), hlm. 32 


\section{Ilzam Kamaludin}

keduanya tidak saling mensifati. Di samping itu, masih banyak kesalahan yang muncul dalam penulisan skripsi mahasiswa jurusan PBA dan BSA di UIN Sunan Kalijaga Yogyakarta.

Hal ini sangat mempengaruhi calon guru bahasa Arab dan calon penerjemah atau penulis bahasa Arab yang dicetak oleh perguruan tinggi tersebut, karena idealnya menjadi guru dan penulis bahasa Arab yang profesional harus menguasai ilmu yang menjadi bidang keahliannya, baik dari metode pengajaran dan keterampilan bahasa resepsif maupun produktif.

Dari uraian di atas, dapat disimpulkan bahwa adanya kesalahan-kesalahan yang terjadi dalam penulisan skripsi bahasa Arab, menunjukkan perlu adanya evaluasi yang berkelanjutan, karena jika kesalahan-kesalahan tersebut tidak segera dievaluasi, kemungkinan besar terdapat kesalahan-kesalahan yang serupa terhadap penulisan skripsi bahasa Arab di masa yang akan datang.

Kesalahan dalam keterampilan menulis berbahasa Arab, dapat terjadi dalam beberapa aspek, di antaranya:

1) Kesalahan aspek morfologis (șorof/bentuk kata), yaitu pembentukan atau perubahan kalimat bahasa Arab baik dari penambahan dan pengurangan. ${ }^{7}$

2) Kesalahan aspek sintaksis (nahwu/susunan kata), yaitu pengetahuan tentang keadaan akhir kata atau kalimat bahasa Arab baik dari segi I'rāb maupun segi bentuk kalimat. ${ }^{8}$

3) Kesalahan idiomatik (ungkapan khusus, termasuk gabungan $f$ ' $i l$ dan huruf jar)

4) Kesalahan aspek makna (semantik), yaitu yang membicarakan tentang makna, perkembangannya, dan perubahan makna dalam bahasa. ${ }^{9}$

Oleh karena ada banyak aspek kesalahan dalam keterampilan menulis berbahasa Arab di atas, maka penulis membatasi dengan kesalahan pada aspek sintaksis dan morfologi yang terkait dengan sintaksis (nahwu), karena kedua aspek tersebut sangat mempunyai keterkaitan satu sama lain.

\section{PEMBAHASAN}

Manusia sebagai makhluk sosial tidak mungkin hidup sendiri dalam arti luas. Ia memerlukan bantuan orang lain. Itulah sebabnya manusia senantiasa hidup berkelompok, bekerja sama, dan berinteraksi di antara sesamanya. Interaksi merupakan perwujudan naluri tiap orang untuk memenuhi kebutuhannya. Salah satu cara memenuhi kebutuhan adalah

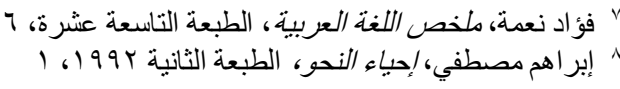

${ }^{9}$ Moh. Matsna, Orientasi Semantik Al-Zamakhsyari, (Jakarta: Anglo Media, 2006), hlm. 3. 
bekerja sama dan bergaul tukar-menukar informasi dan pengalaman. Untuk menyatakan isi gagasan atau batinnya, manusia mutlak memerlukan alat pengungkap yang sempurna. Alat itu adalah bahasa.

Bahasa merupakan alat utama untuk berkomunikasi dalam kehidupan manusia, baik secara individual maupun kolektif sosial. Secara indvidual, bahasa merupakan alat untuk mengekspresikan isi gagasan bathin kepada orang lain. Secara kolektif sosial, bahasa merupakan alat berinteraksi dengan sesamanya. ${ }^{10}$

Belajar bahasa seperti halnya bentuk-bentuk belajar sesuatu yang lain. Selinker (1972) via Pranowo mengatakan kekeliruan yang diperbuat oleh pembelajar selama dalam proses belajar tidak dapat dipandang sebagai kesalahan begitu saja tetapi harus dipandang sebagai suatu bagian dari strategi belajar. Bahasa yang dipakai atau dikuasi oleh seseorang yang sedang dalam proses belajar bahasa disebut bahasa antara. ${ }^{11}$ Dengan pengertian lain bahwa bahasa antara merupakan bahasa yang dihasilkan oleh seseorang yang sedang dalam proses menguasai bahasa kedua. Ciri utama bahasa antara (interlanguage) adalah adanya penyimpangan struktur lahir dalam bentuk kesilapan (errors) berbahasa. Kesilapan-kesilapan ini bersifat sistematis dan terjadi pada setiap orang yang berusaha menguasai bahasa kedua. ${ }^{12}$

Kesalahan-kesalahan berbahasa demikian, Corder (1971) membedakan istilah salah (mistake), selip (lapses), dan silap (errors). salah (mistake) adalah penyimpangan struktur lahir yang terjadi karena penutur tidak mampu menentukan pilihan penggunaan ungkapan yang tepat sesuai dengan situasi yang ada. selip (lapses) merupakan penyimpangan bentuk lahir karena beralihnya pusat perhatian topik pembicaraan secara sesaat. Kelelahan tubuh bisa menimbulkan selip bahasa. Dengan demikian selip bahasa terjadi secara tidak disengaja. silap (errors) merupakan penyimpangan bentuk lahir dari struktur baku yang terjadi karena pemakai belum menguasai sepenuhnya kaidah bahasa. Faktor yang mendorong timbulnya kesilapan adalah faktor kebahasaan yang mengikuti pola-pola tertentu. ${ }^{13}$

${ }^{10}$ Suwarna Pringgawidagda, Strategi Penguasaan Berbahasa, (Yogyakarta: Adicita Karya Nusa, 2004), hlm.

${ }^{11}$ Pranowo, Analisis Pengajaran Bahasa untuk mahasiswa jurusan bahasa dan guru bahasa, (Yogyakarta: Gadjah Mada University Press, 1996), hlm. 50.

${ }^{12}$ Pranowo, Teori Belajar Bahasa, (Yogyakarta: Pustaka Pelajar), 2015, hlm. 122.

${ }^{13}$ Pranowo, Analisis Pengajaran, hlm. 51. 


\section{Ilzam Kamaludin}

Usaha untuk membantu tercapainya tujuan belajar bahasa pembelajar adalah mengetahui sebab-sebab dan cara mengatasi kekeliruan-kekeliruan berbahasa yang mereka lakukan. ${ }^{14}$ Kemudian, penelitian ini dimaksudkan untuk mengungkap sebab-sebab kekeliruan sintaksis bahasa Arab pada aspek al-murakkabāt dalam keterampilan menulis.

Maka dari itu, tulisan ini menggunakan teori analisis kesalahan berbahasa (anakes), Ellis (1987) mengatakan dalam buku Henry Guntur Tarigan yaitu suatu prosedur yang digunakan oleh para peneliti dan para guru yang mencakup pengumpulan sampel bahasa pelajar, pengenalan kesalahan-kesalahan yang terdapat dalam kesalahan tersebut, pendeskripsian kesalahan-kesalahan itu, pengklasifiannya berdasarkan sebab-sebabnya yang telah dihipotesiskan serta pengevaluasian keseriusannya. ${ }^{15}$

Analisis kesalahan berbahasa berasumsi bahwa pengajaran bahasa hendaknya lebih difokuskan pada frekuensi terbesar kesalahan pembelajar. Penulusuran faktor-faktor penyebab kesalahan-kesalahan serta jenis-jenis kesalahan yang dilakukan oleh pembelajar jauh lebih penting karena dapat digunakan sebagai dasar untuk memperbaiki kesalahan belajar dan kesalahan berbahasa pembelajar. ${ }^{16}$

\section{Keterampilan Menulis}

Dalam kehidupan modern ini jelas bahwa keterampilan menulis sangat dibutuhkan. Kiranya tidaklah terlalu berlebihan bila kita katakan bahwa keterampilan menulis merupakan suatu ciri dari orang yang terpelajar atau bangsa yang terpelajar. Sehubungan dengan hal ini ada seorang penulis yang mengatakan bahwa "menulis dipergunakan oleh orang terpelajar untuk mencatat/merekam, meyakinkan, melaporkan/memberitahukan, dan mempengaruhi dan maksud serta tujuan seperti itu hanya dapat dicapai dengan baik oleh orang-orang yang dapat menyusun pikirannya dan mengutarakannya dengan jelas, kejelasan ini tergantung pada pikiran, organisasi, pemakaian kata-kata, dan struktur kalimat, menurut Morsey (1976) via Tarigan. $^{17}$

\section{Pengertian Menulis}

Menulis merupakan suatu kegiatan komunikasi berupa penyampaian pesan (informasi) secara tertulis kepada pihak lain dengan menggunakan bahasa tulis sebagai alat atau medianya.

\footnotetext{
${ }^{14}$ Pranowo, Analisis Pengajaran, hlm. 50-51.

${ }^{15}$ Henry Guntur Tarigan, Pengajaran Analisis Kesalahan Berbahasa, (Bandung:Angkasa, 2011), hlm. 153.

${ }^{16}$ Pranowo, Analisis Pengajaran, hlm. 3.

${ }^{17}$ Henry Guntur Tarigan, Pengajaran, hlm. 3-4
} 
Aktivitas menulis melibatkan beberapa unsur, yaitu: penulis sebagai penyampaian pesan, isi tulisan, saluran atau media dan pembaca.

Menulis merupakan sebuah proses kreatif menuangkan gagasan dalam bentuk bahasa tulis dalam tujuan, misalnya memberitahu, meyakinkan atau menghibur. Hasil dari proses kreatif ini biasanya disebut dengan istilah karangan atau tulisan. Kedua istilah tersebut mengacu pada hasil yang sama meskipun ada pendapat yang mengatakan kedua istilah tersebut memiliki pengertian yang berbeda. Istilah menulis sering melekatkan pada proses kreatif yang sejenis ilmiah. Sementara istilah mengarang sering diletakkan pada proses kreatif yang berjenis nonilmiah.

Menulis juga dapat dikatakan sebagai kegiatan merangkai huruf menjadi kata atau kalimat untuk disampaikan kepada orang lain, sehingga orang lain dapat memahaminya. Dalam hal ini, dapat terjadinya komunikasi antarpenulis dan pembaca dengan baik.

Sejalan dengan pendapat diatas, Marwoto (1987) dalam bukunya Dalman menjelaskan bahwa menulis adalah mengungkapkan ide atau gagasannya dalam bentuk karangan secara leluasa. Dalam hal ini, menulis itu membutuhkan skemata yang luas sehingga dengan mudah dan lancar. Skemata itu sendiri adalah pengetahuan dan pengalaman yang dimiliki. Jadi semakin luas skemata seseorang, semakin mudahlah ia menulis.

Berdasarkan pendapat para pakar di atas dapat disimpulkan bahwa menulis adalah proses penyampaian pikiran, angan-angan, perasaan dalam bentuk lambang/tanda/tulisan yang bermakna. $^{18}$

Menulis merupakan suatu bentuk manifestasi kemampuan berbahasa paling akhir dikuasai pelajar bahasa setelah kemampuan menyimak, bercakap, dan membaca. Dibanding tiga kemampuan berbahasa yang lain, keterampilan menulis lebih sulit dikuasai bahkan oleh penutur bahasa yang bersangkutan sekalipun.

Supaya seseorang dapat menulis secara runtut dan padu, diperlakukan penguasaan yang memadai mengenai berbagai unsur kebahasaan dan unsur di luar bahasa itu sendiri yang akan menjadi isi tulisan atau karangan. Penguasaan terhadap sistem ejaan kosakata, dan struktur tata bahasa harus dimiliki oleh siswa untuk dapat melakukan kegiatan menulis. ${ }^{19}$

\section{Sintaksis Bahasa Arab Al-Murakkabāt}

\footnotetext{
${ }^{18}$ Dalman, Keterampilan, hlm. 3-4

${ }^{19}$ Moh. Matsna, Erta Mahyudin, Pengembangan Evaluasi dan Tes Bahasa Arab, (Tangerang Selatan: Alkitabah, 2012), hlm. 161
} 


\section{Ilzam Kamaludin}

Sintaksis dalam bahasa Arab sering disebut dengan kata nahwu yang berarti pengetahuan tentang keadaan akhir kata atau kalimat bahasa Arab baik dari segi I'rāb maupun segi bentuk kalimat. ${ }^{20}$ Dalam nahwu sangat banyak pembahasan tentang sintaksis bahasa arab, namun dalam hal ini hanya dibatasi dengan sintaksis bahasa Arab yang disebut dengan (al-murakkab atau al-tarkīb) yaitu suatu perkataan yang terdiri dari dua kalimat atau lebih yang mempunyai faidah tertentu. Al-murakkab terbagi menjadi enam macam, ${ }^{21}$ yaitu:

1. Al-Murakkab al-Isnādy/al-Jumlah, yaitu ungkapan suatu hal yang disandarkan dengan hal lain, seperti ungkapan zuhair dengan ijtihad (bersungguh-sungguh), maka dalam perkataan menjadi zuhairun mujtahidun (zuhair itu bersungguh-sungguh). Dengan pengertian lain bahwa al-Murakkab al-Isnādy/al-Jumlah adalah suatu kalimat yang tersusun dengan musnad dan musnad ilaih.

Macam-macam musnad adalah:

الفعل، واسم الفعل، وخبر المبتدأ، وخبر الفعل الناقص، وخبر الأحرف التى تعمل عمل (ليس)، وخبر إن وأخواتها.

Sedangkan macam-macam musnad ilaih, adalah:

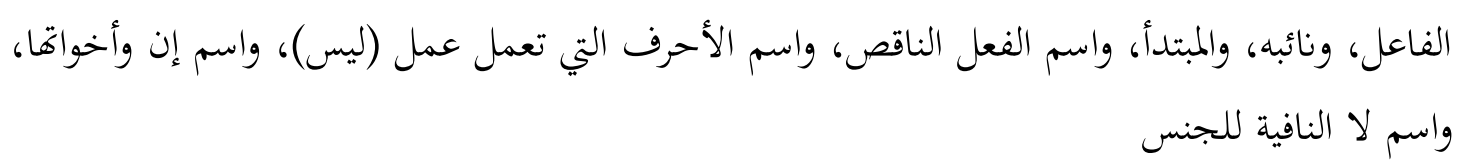

2. Al-Murakkab al-I $\underline{a} a \overline{f y}$, yaitu suatu kalimat yang tersusun dengan mudāf dan mudāf ilaih.

Contoh: كتاب التلميذ، باب الصلاة

3. Al-Murakkab al-Bayāny, yaitu setiap dua kalimat, dimana kata kedua memperjelas

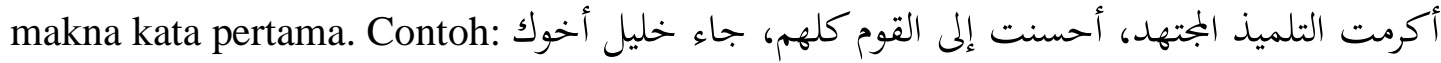

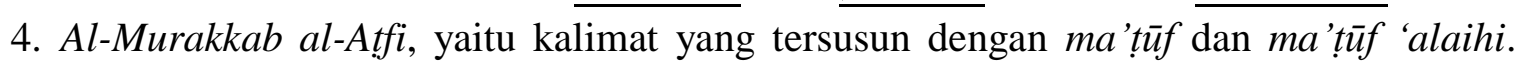
Contoh: ينال التلميذ والتلميذة الحمد

5. Al-Murakkab al-Mazjy, yaitu setiap susunan dua kalimat yang dijadikan satu kalimat. Contoh: حضرموت، سيبويه

6. Al-Murakkab al-'Adady, Sintaksis ini bagian dari al-murakkabat al-mazjiyah yaitu setiap bilangan diantaranya huruf 'atf yang tidak tampak (tidak disebutkan). Yaitu bilangan angka 11-19 dan bilangan angka yang ke-11sampai ke-19.

\section{Metode Penelitian}

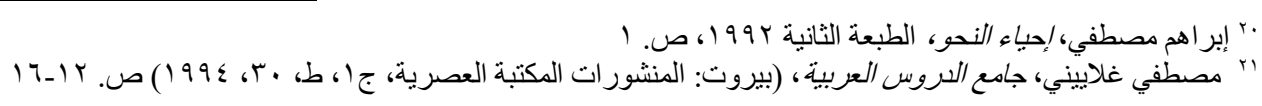

59 An-Nas: Jurnal Humaniora, Vol.3, No. 1, 2019 
Metode penilaian ini dimaksudkan untuk pengungkapan masalah yang sedang dianalisis, adapun metode yang digunakan dalam penelitian ini adalah:

1. Jenis Penelitian

Penelitian ini termasuk penelitian kualitatif dimana data disajikan dengan pemaparan kata-kata namun jika dari penelitian ini kemudian muncul angka-angka, maka keberadaannya sebagai data penunjang. Analisis kuantitatif digunakan untuk pengembangan analisis data kualitatif tersebut sesuai dengan kebutuhan dalam rangka mempertajam atau memperkaya analisis kualitatif itu sendiri. ${ }^{22}$

Penelitian ini termasuk penelitan deskriptif yang melakukan penyajian fakta secara sistematis sehingga dapat dipahami dan disimpulkan, yaitu mengumpulkan data atau informasi untuk disusun, dijelaskan, dan dianalisis. ${ }^{23}$ Analisis kesalahan berbahasa termasuk penelitian evaluatif, yaitu untuk mengetahui kondisi hasil akhir dari adanya kebijakan untuk kemudian menentukan rekomendasi atas kebijakan yang lalu guna menentukan kebijakan selanjutnya. ${ }^{24}$ Penelitian ini juga termasuk penelitian studi kasus yaitu menyelidiki secara mendalam tentang suatu hal pada suatu satuan social, seperti individu, kelompok, lembaga, atau komunitas. ${ }^{25}$

Kasus dalam penelitian ini adalah kesalahan-kesalahan sintaksis bahasa Arab yang terjadi dalam penulisan skripsi jurusan Pendidikan Bahasa Arab di FITK dan Bahasa dan Sastra Arab di FADIB UIN Sunan Kalijaga Yogyakarta tahun 2015-2017.

2. Sumber dan Teknik Pengumpulan Data

Data utama dalam penelitian ini adalah kesalahan-kesalahan yang terjadi pada skripsi berbahasa Arab yang di tulis oleh 4 Mahasiswa Jurusan PBA di FITK dan 3 Mahasiswa Jurusan BSA di FADIB UIN Sunan Kalijaga. Pengumpulan data yang dilakukan peneliti menggunakan File/Soft Copy skripsi asli tanpa adanya perubahan sedikitpun, sehingga dapat mempermudah peneliti dalam menganalisis kesalahankesalahan tersebut. Setelah pengumpulan data kesalahan yang ada dalam skripsi tersebut, kemudian dilakukan pengklasifikasian berdasarkan kategori sintaksis bahasa

\footnotetext{
${ }^{22}$ Mahsun, Metodologi Penelitian Bahasa: Tahapan Strategi, Metode, dan Teknisnya, (Jakarta: PT Grafindo Persada, 2005), hlm. 257-258

${ }^{23}$ Margono S, Metodologi Penelitian Pendidikan, (Jakarta: Rineka Cipta, 2003), hlm. 8.

${ }^{24}$ Suharsimi Arikunto, dkk, Evaluasi Program Pendidikan, (Jakarta: PT Bumi Aksara, 2009), hlm. 7.

${ }^{25}$ Saifudin Azwar, Metode Penelitian, (Jakarta: Pustaka Pelajar, 2009), hlm. 8.
} 


\section{Ilzam Kamaludin}

Arab yang telah ditentukan oleh peneliti dan menunjukkan letak kesalahankesalahannya, selanjutnya dilakukan evaluasi untuk memperbaiki kesalahan-kesalahan tersebut, kemudian diakumulasikan seberapa banyak kesalahan penulisan dari kedua jurusan tersebut.

\section{Analisis Data}

Analisis terhadap kesalahan sintaksis bahasa Arab dalam penulisan skripsi, dilakukan dengan analisis isi, yaitu suatu jenis metode dalam penelitian dengan melakukan pembahasan secara mendalam terhadap data tersebut melalui beberapa langkah, yaitu:

a) Identifikasi Kesalahan, yaitu membaca kata demi kata terhadap skripsi dengan cermat dan teliti, kemudian menentukan kesalahan dengan mencatat dalam tabel dan disusun secara sistematis dan juga melakukan perbaikan dari kesalahan tersebut.

b) Klasifikasi Kesalahan, yaitu kesalahan yang telah dikumpulkan dari jumlah data, kemudian diklasifikasikan ke dalam kategori sintaksis bahasa Arab yang sesuai berdasarkan kesalahannya.

c) Penjelasan Kesalahan, yaitu penguraian kesalahan dalam kategori sintaksis bahasa Arab, Penguraian tersebut meliputi contoh serta letak kesalahannya.

4. Pembenaran/Perbaikan Temuan

Peneliti menggunakan teknik pentashihan (pembenaran) data berupa membaca secara berulang dengan lebih cermat dan lebih teliti terhadap jumlah data sehingga mendapatkan hasil yang shahih. Peneliti juga mengacu kepada kitab-kitab tentang alQawā'id al-'Arabiyyah dalam menganalisis data tersebut, seperti:

a) Kitab al-Nahwu al-Wāḍh, karangan 'Ali al-Jārim dan Muștofa Amīn

b) Kitab Qowā'id al-Lugah al- 'Arabiyyah (mulakhoṣ), karangan Fuād Nu'amah

c) Kitab Jamī' al-Durūs al- 'Arabiyyah, karangan Syaikh Musțofa al-Golāyaini

Kemudian meminta ahli khususnya dalam aspek sintaksis bahasa Arab untuk mengoreksi dan membenarkan hasil temuan data peneliti terhadap kesalahan sintaksis bahasa Arab dalam penulisan skripsi, sehingga data-data tersebut lebih dapat dipertanggung jawabkan.

\section{Objek Penelitian}


Objek penelitian ini adalah skripsi mahasiswa jurusan Pendidikan Bahasa Arab di FITK dan skripsi mahasiswa jurusan Bahasa dan Sastra Arab di FADIB Universitas Islam Negeri Sunan Kalijaga Yogyakarta, di antaranya adalah:

Objek penelitian dari Skripsi Mahasiswa Jurusan Pendidikan Bahasa Arab di FITK UIN Sunan Kalijaga Yogyakarta, antara lain:

Pertama, skripsi yang berjudul:

$$
\text { الثانوية الإسلامية الارتباط بين إتقان المفردات والقواعد بالقدرة على الكتابة العربية لطلاب الفصل العاشر للعلم الديني بالمدرسة واحد سليمان يوكياكارتا في العام الدراسي } 2016 / 2017
$$

ditulis oleh Haerul Ahyar yang diuji pada tahun 2017.

Kedua, skripsi yang berjudul:

تنفيذ استراتيجية التعليم النشطي المبتكر والخلاق والفعال والممتع PAIKEM في تعليم اللغة العربية للفصل الثامن بمعهد ابن القيم الإسلامي للبنات جوكجاكرتا. ditulis oleh Arbi Mulya Sirait,yang diuji pada tahun 2015.

Ketiga, skripsi yang berjudul:

$$
\text { وسائل الإيضاح) بيونجان بانتول جوكجاكرتا. }
$$

ditulis oleh Rojingana Sulaiman yang diuji pada tahun 2016.

Keempat, skripsi yang berjudul:

تعليم كتاب متن الأجرومية للفصل الثامن من الأولية في المدرسة الدينية نور الأمة للبنين كوتا غيدي يوكياكرتا yang ditulis oleh Muhammad Anniquzzaim yang diuji pada tahun 2017.

Kemudian objek Penelitian dari Skripsi Mahasiswa Jurusan Bahasa dan Sastra Arab di FADIB UIN Sunan Kalijaga Yogyakarta, antara lain:

Pertama, skripsi yang berjudul:

ترجمة كتاب "انقاذ الأمة" للشيخ محمد أبي الهدي اليعقوبي مشكلات ترجمة التراكيب الوصفية المنسوبة صفتها بياء

Ditulis oleh M. Faishal Khoirurijal yang diuji pada tahun 2017.

Kedua, skripsi yang berjudul:

$$
\text { أسلوب الأمر في سورة النساء (دراسة تحليلية في علم المعاني) }
$$

Ditulis oleh Adam Surya Nugraha yang diuji pada tahun 2017.

Ketiga, skripsi yang berjudul:

$$
\text { الأفعال الكلامية للأوامر في سورة البقرة (دراسة تحليلية تداولية) }
$$

Ditulis oleh Mustika yang diuji pada tahun 2017. 


\section{Ilzam Kamaludin}

Pengambilan data kesalahan sintaksis dalam penulisan skripsi berbahasa Arab terhadap penelitian ini tidak tergantung dari banyaknya sampel, karena tujuan dari penelitian ini bukan kuantitatif, melainkan menemukan atau menampilkan kesalahan-kesalahan sintaksis yang muncul dalam penulisan skripsi berbahasa Arab, mengkategorikan, dan memberikan penjelasan dari bentuk kesalahan yang telah ditemukan peneliti.

Dalam artikel ini, penulis tidak melakukan penelitian terhadap semua bab dalam skripsi yang ada, tetapi lebih fokus kepada bab pertama dan kesimpulan karena bab tersebut lebih diperhatikan oleh penulis dan pembimbing skripsi sehingga pembahasan tersebut membutuhkan seluruh kemampuan dan kesungguhan penulis dari adanya penelitian yang telah dilakukan.

Setelah penulis mengaplikasan teori analisis kesalahan bahasa terhadap sampel yang telah disebutkan di atas, kemudian penulis menemukan beberapa kesalahan yang muncul dalam penulisan skripsi mahasiswa jurusan PBA di FITK dan BSA di FADIB UIN Sunan Kalijaga Yogyakarta. Beberapa kesalahan sintaksis al-Murakkabāt yang ditemukan oleh penulis meliputi kesalahan dalam pembentukan jumlah fi'liyyah, jumlah ismiyyah, iḍafah, na'at man 'ūt, kesalahan damīr, dan masih banyak bentuk kesalahan ta'bīr yang lain. ${ }^{26}$

\section{Kesimpulan}

Kesalahan sintaksis pada aspek al-murakkabāt dari skripsi jurusan Pendidikan Bahasa Arab di Fakultas Ilmu Tarbiyah dan Keguruan dan jurusan Bahasa dan Sastra Arab di Fakultas Adab dan Ilmu Budaya UIN Sunan Kalijaga Yogyakarta ditemukan sejumlah 207 kesalahan. Rincian kesalahan al-murakkabāt, sebagai berikut:

a. Kesalahan Jumlah Fi'liyyah ditemukan sejumlah 26 kesalahan

b. Kesalahan Jumlah Ismiyyah ditemukan sejumlah 11 kesalahan

c. Kesalahan Na'at Man'üt ditemukan sejumlah $\wedge$ r kesalahan

d. Kesalahan I⿳亠㐅a $f a h$ ditemukan sejumlah 49 kesalahan

e. Kesalahan $M a$ 't $\bar{u} f$ dan $M a^{\prime} t \underline{u} f$ 'alaihi ditemukan sejumlah 17 kesalahan

${ }^{26}$ M Ilzam Kamaludin, Kesalahan Sintaksis pada Skripsi Mahasiswa S1 (Studi Kasus Kesalahan Sintaksis terhadap Penulisan Skripsi Mahasiswa Jurusan Pendidikan Bahasa Arab di Fakultas Ilmu Tarbiyah dan Keguruan dan Jurusan Bahasa dan Sastra Arab di Fakultas Adab dan Ilmu Budaya UIN Sunan Kalijaga Yogyakarta), Tesis 2018 (tidak diterbitkan) 
f. Kesalahan Damīr ditemukan sejumlah 13 kesalahan

g. Kesalahan Isim Maușūl ditemukan sejumlah 9 kesalahan

h. Kesalahan 'Adad Ma'dūd ditemukan sejumlah 1 kesalahan

Data kesalahan yang ditemukan oleh penulis, baik dari identifikasi kesalahan, kategori kesalahan, penjalasan dan perbaikan kesalahan ta'bīr mengacu pada kitab al-Qawā'id al'Arabiyyah di antaranya adalah al-Nahwu al-Wādih, Qowā'id al-Lugah al-'Arabiyyah (mulakhoṣ), dan Jamī'al-Durūs al- 'Arabiyyah.

\section{DAFTAR PUSTAKA}

Wahab, Abd., Rosyidi dan Mamlu'atul Ni'mah, Memahami Konsep Dasar Pembelajaran Bahasa Arab, Malang: UIN-Maliki Press, 2012.

Chaer, Abdul, Sintaksis Bahasa Indonesia (Pendekatan Proses), Jakarta: Rineka Cipta, 2009. Fachrurrozi, Aziz dan Erta Mahyuddin, Teknik Pembelajaran Bahasa Arab, Bandung: Pustaka Cendekia Utama, 2011.

Azwar, Saifudin, Metode Penelitian, Jakarta: Pustaka Pelajar, 2009.

Dalman, Keterampilan Menulis, Jakarta: PT RajaGrafindo Persada, 2012

Guntur, Henry Tarigan, Pengajaran Analisis Kesalahan Berbahasa, Bandung:Angkasa, 2011

Guntur, Henry Tarigan, Pengajaran Remidi Bahasa, Bandung: Percetakan Angkasa, 2009

Heri Jauhari, Terampil Mengarang, Bandung: Nuansa Cendikia, 2013

Mahsun, Metodologi Penelitian Bahasa: Tahapan Strategi, Metode, dan Teknisnya, Jakarta: PT Grafindo Persada, 2005

Matsna, Moh, Erta Mahyudin, Pengembangan Evaluasi dan Tes Bahasa Arab, Tangerang Selatan: Alkitabah, 2012

Matsna, Moh, Orientasi Semantik Al-Zamakhsyari, Jakarta: Anglo Media, 2006

Markhamah, Ragam dan Analisis Kalimat Bahasa Indonesia, Surakata: Muhammadiyah University Press, 2011

Pangesti Wiedarti, Menuju Budaya Menulis Suatu Bunga Rampai, Yogyakarta: Tiara Wacana, 2005

S, Margono, Metodologi Penelitian Pendidikan, Jakarta: Rineka Cipta, 2003

Pranowo, Analisis Pengajaran Bahasa untuk mahasiswa jurusan bahasa dan guru bahasa, Yogyakarta: Gadjah Mada University Press, 1996

Pranowo, Teori Belajar Bahasa, Yogyakarta: Pustaka Pelajar, 2015 


\section{Ilzam Kamaludin}

Pringgawidagda, Suwarna, Strategi Penguasaan Berbahasa, Yogyakarta: Adicita Karya Nusa, 2002

Arikunto, Suharsimi, dkk, Evaluasi Program Pendidikan, Jakarta: PT Bumi Aksara, 2009

D, J. Parera, Dasar-dasar Analisis Sintaksis, Jakarta: Erlangga, 2009

Nasir, Zulhasril, Menulis untuk Dibaca, Jakarta: Yayasan Pustaka Obor Indonesia, 2010

Mansyur, Moh Kustiwan, دليل الكاتب والمرتجم, Jakarta: Moyo Segoro Agung, 2002

Suadi, “Dialek-dialek Bahasa Arab”, jurnal adabiyyāt, no.1, tahun 2008, 75

Syamsi Setiadi, "Peningkatan Keterampilan Kitabah Arabiyah Mahasiswa Melalui Metode

Tutor Sebaya”, jurnal al-bayān, No. 1 tahun 2017, 31

Fauzi, Helmy Awaliyah, "Analisis Kesalahan Berbahasa Studi Kasus Aspek Morfologis dan

Sintaksis terhadap Penulisan Skripsi jurusan Pendidikan Bahasa Arab UIN Sunan

Kalijaga dan UIN Maulana Malik Ibrahim Priode Wisuda 2013-2014”,Tesis 2017

M Ilzam Kamaludin, "Kesalahan Sintaksis pada Skripsi Mahasiswa S1 (Studi Kasus Kesalahan

Sintaksis terhadap Penulisan Skripsi Mahasiswa Jurusan Pendidikan Bahasa Arab di

Fakultas Ilmu Tarbiyah dan Keguruan dan Jurusan Bahasa dan Sastra Arab di Fakultas Adab dan Ilmu Budaya UIN Sunan Kalijaga Yogyakarta)”, Tesis 2018

$$
\begin{aligned}
& \text { فخر، عزيز، الرازي ومحصن نووي، أماليب المهارات اللغوية العببية، جاكرتا: قسم اللغة العربية كلية التربية والتعليم }
\end{aligned}
$$

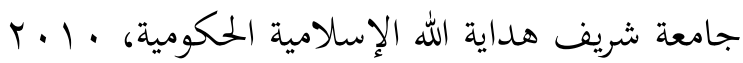

$$
\begin{aligned}
& \text { إبراهم مصطفي، إحياء النحو، الطبعة الثانية بو } 999 \\
& \text { فؤاد نعمة، ملخص اللغة العببية، الطبعة التاسعة عشرة }
\end{aligned}
$$

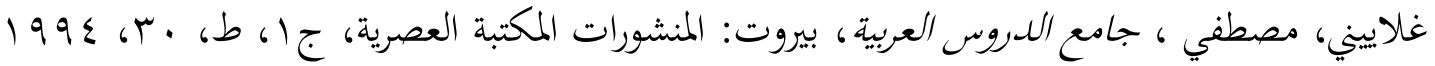

$$
\begin{aligned}
& \text { خير الأخيار، "دراسة الارتباط بين إتقان المفردات والقواعد بالقدرة على الكتابة العربية لطلاب الفصل العاشر للعلم }
\end{aligned}
$$

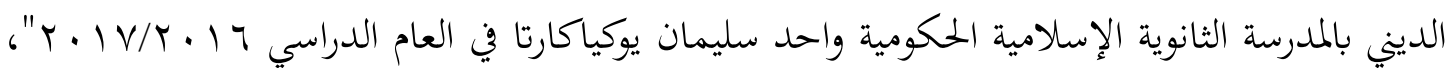

$$
\begin{aligned}
& \text { جامعة سونان كليجاكا الإسلامية الحكومية جوكجاكرتا } \\
& \text { محمد فيصل خير الرجال، "ترجمة كتاب "انقاذ الأمة" للشيخ محمد أبي الهدي اليعقوبي مشكلات ترجمة التراكيب } \\
& \text { الوصفية المنسوبة صفتها بياء النسبة"، جامعة سونان كليجاكا الإسلامية الحكومية جوكجاكرتا، } \\
& \text { أربي موليا صراط، "تنفيذ استراتيجية التعليم النشطي المبتكر والخلاق والفعال والممتع PAIKEM في تعليم اللغة } \\
& \text { العربية للفصل الثامن بمعهد ابن القيم الإسلامي للبنات جوكجاكرتا"، جامعة سونان كليجاكا الإسلامية } \\
& \text { الحكومية جوكجاكرتا }
\end{aligned}
$$


راجينجان سليمان، "دور القصص المصورة في تعليم اللغة العربية كتاب التعبير في الفصل العاشر معهد ابن القيم للبنين ( دراسة عن وسائل الإيضاح) بيونجان بانتول جوكجاكرتا"، جامعة سونان كليجاكا الإسلامية

$$
\text { الحكومية جوكجاكرتا، ص. }
$$

أدم سوريا نوغراها، "أسلوب الأمر في سورة النساء (دراسة تحليلية في علم المعاني)"، جامعة سونان كليجاكا الإسلامية

$$
\text { الحكومية جوكجاكرتا }
$$

محمد عنيق الزائم، "تعليم كتاب متن الأجرومية للفصل الثامن من الأولية في المدرسة الدينية نور الأمة للبنين كوتا غيدي يوكياكرتا"، جامعة سونان كليجاكا الإسلامية الحكومية جوكجاكرتا

موستيكا، "الأفعال الكلامية للأوامر في سورة البقرة (دراسة تحليلية تداولية)"، جامعة سونان كليجاكا الإسلامية الحكومية جوكجاكرتا 